\title{
Memahami Tingkatan Spiritual Manusia Dalam Mendeteksi Krisis Nilai Moral
}

\section{Understanding the Human Spiritual Rank In Detecting Moral Crisis Values}

\author{
Nirwani Jumala* \\ Madrasah Tsanawiyah Negeri 2 Aceh Besar, Nangroe Aceh Darussalam, Indonesia
}

\begin{abstract}
Abstrak
Penelitian ini bertujuan untuk mengetahui tingkatan spiritual manusia yang mempengaruhi nilai moral, penyebab krisis moral, dan solusi terhadap permasalahan nilai moral. Nilai moral adalah sifat-sifat atau hal-hal yang penting atau berguna bagi kemanusian yang dilakukan secara terencana untuk mengubah sikap, perilaku, tindakan, kelakuan agar mampu berinteraksi dengan lingkungan masyarakatnya sesuai dengan nilai agama dan moral serta kebudayaan masyarakat setempat. Ada beberapa hal yang melatarbelakangi kemerosotan moral saat ini dan hal itu perlu diketahui sehingga kita mampu menemukan solusi yang terbaik dan membantu dalam penyelesaian masalah tersebut. Dalam pandangan Islam, terdapat tujuh tingkatan spiritualitas manusia dari yang bersifat egoistik sampai yang suci menurut perintah Allah. Tingkatan itu terdiri dari nafs amarah, nafs lawwamah, nafs mulhimma, nafs muthmainnah, nafs radhiyah, nafs mardhiah dan nafs safiyah. Penyebab krisis nilai moral tersebut antara lain: longgarnya pegangan terhadap agama, kurangnya internalisasi nilai moral melalui pendidikan karakter, derasnya arus budaya materialistis, hedonistis dan sekularististis dan penyalalahgunaan sebagian ajaran moral serta.perkembangan Teknologi. Beberapa solusi yang dapat dilakukan untuk mengatasi krisis nilai moral ini adalah menghargai sesama manusia, mendekatkan diri kepada Allah dan menguatkan fungsi pendidikan.
\end{abstract}

Kata Kunci: Krisis, Nilai Moral, Solusi

\begin{abstract}
This study aims to determine the spiritual level of humans that affect the moral value, the cause of moral crisis, and solutions to the problems of moral values. The moral value is the nature or matters that are important or useful for the humanity that is done in a planned way to change the attitude, behavior, actions, behavior in order to be able to interact with the community environment according to the religious and moral values and culture of the local community. There are some things that lie behind the current moral decline and it needs to be known so that we can find the best solution and help in solving the problem. In the view of Islam, there are seven levels of human spirituality from the egoistic to the sacred according to God's command. The level consists of anger nafs, nafs lawwamah, nafs mulhimma, nafs muthmainnah, nafs radhiyah, nafs mardhiah and nafs safiyah. The causes of the moral value crisis include: laxness of religion, lack of internalization of moral values through character education, the rapid flow of materialistic, hedonistic and secularisticistic culture and the misuse of some moral teachings and technological developments. Some solutions that can be done to overcome this moral value crisis is to respect the fellow human beings, draw closer to God and strengthen the function of education.

Keywords: Crisis, moral value, solution
\end{abstract}

How to Cite: Jumala, N., (2017). Memahami Tingkatan Spiritual Manusia dalam Mendeteksi Krisis Nilai Moral. JPPUMA: Jurnal Ilmu Pemerintahan dan Sosial Politik, 5 (1):42-5o.

\begin{tabular}{lr}
\hline *Corresponding author: & p-ISSN: 25491660 \\
E-mail: armansyah@staff.uma.ac.id & e-ISSN: 2550-1305
\end{tabular}




\section{PENDAHULUAN}

Sebuah nasehat menyebutkan bahwa yang kekal di dunia ini hanyalah perubahan, oleh karena itu mau atau tidak mau setiap seseorang harus berhadapan dengan perubahan. Tumbuhnya kekuatan internal yang mengubah hubungan seseorang dengan Tuhan dan masyarakatnya akan timbul pada diri seseorang dengan meningkatnya kesadaran, dimana nilai-nlai ketuhanan di dalam dirinya akan termanifestasi ke luar melalui pengalaman dan kemajuan diri (Aliah, 2009:289)

Perubahan itu dapat menuju ke arah positf, dapat juga menuju arah negatif. Maka untuk menghasilkan perubahan positif, seseorang harus mengetahui langkah-langkah untuk berubah menjadi semakin baik, melalui internalisasi nilainilai agama dan norma yang merupakan proses pemasukan nilai yang diharapkan akan mampu membentuk pola pikir seseorang dalam memahami berbagai realitas dan pengalaman. Pemaknaan atas nilai ini juga akan mewarnai sikap terhadap diri, lingkungan dan kenyataan di sekelilingnya, sehingga dampak negatif perubahan tatanan sosial, perkembangan ilmu pengetahuan dan globalisasi tidak menjerumuskan kepada tindakantindakan yang melanggar syariat agama dan melanggar peraturan negara.

Internalisasi nilai yang sempurna akan mendorong seseorang melakukan eksternalisasi nilai sebagai usaha mengekspresikan atas redefinisi terhadap nilai yang selama ini diyakini sebagai kebenaran. Ekspresi ini diwujudkan kepada orang lain atau kelompok yang secara kuantitatif lebih besar dengan tujuan untuk mewarnai atau bahkan dalam kondisi ekstrim merubah nilai-nilai semula dengan nilai baru yang diyakini kebenarannya.

Seseorang akan belajar banyak halhal positif dari menunaikan ibadah, diantaranya belajar sabar, terbiasa menanggung beban berat, mengekang hawa nafsu, taat kepada peraturan, mecintai orang lain, memiliki rasa solodaritas, mau memberikan bantuan kepada orang yang membutuhkan, mau menolong, memiliki tanggung jawab sosial dan masih banyak hal positif lainnya yang akan membimbing kepada akhlak mulia.

Namun demikian, akhir-akhir ini kita mendapatkan fenomena lahirnya generasi yang rapuh dengan ciri ciri cepat berputus asa, tidak memiliki komitmen terhadap usaha mencapai kesuksesan hidup duniawi dan ukhrawi, terputus naluri sosial dan empati, galau dan labil, sering berkeluh kesah, cenderung depresi, mudah terpengaruh dengan budaya sesat, mereka hidup dengan pikiran buntu, sehingga memilih bunuh diri atau membunuh orang lain untuk membebaskan diri dari masalah.

Kasus-kasus seperti penyebaran aliran kesesatan, tindak kekerasan, penyimpangan perilaku, penyelewengan tanggung jawab, pencabulan, kebebasan seksual, penggunaan narkotika dan zat-zat adiktif, merupakan indikator lunturnya nilai. Gejala degradasi moral masyarakat semakin memprihatinkan antar lain rendahnya rasa tanggung jawab, disiplin, lunturnya sifat jujur, amanah dan integritas diri terhadap lingkungan. Bahkan demoralisasi dan dehumanisasi telah menjadi gejala umum dalam kehidupan di sekitar kita seperti tingginya tindakan kriminal, maraknya kekerasan, membudayanya korupsi, rendahnya penerapan nilai spiritual dalam kehidupan sehari-hari. Oleh karena itu, untuk menemukan solusi konkret dari permasalahan krisis nilai tersebut perlu diketahui terlebih dahulu penyebab krisis nilai agama dan moral berdasarkan tingkatan spiritual Manusia.

\section{PEMBAHASAN \\ Tingkatan Spiritual Manusia Yang Mempengaruhi Kondisi Moral}

Dalam pandangan Islam, terdapat tujuh tingkatan spiritualitas manusia dari yang bersifat egoistik sampai yang suci menurut perintah Allah. Tingkatan itu terdiri dari nafs amarah, nafs lawwamah, nafs mulhimma, nafs muthmainnah, nafs 
radhiyah, nafs mardhiah dan nafs safiyah (Hasan, 2009: 308)

Nafs Amarah (The Commading Self) merupakan tingkat terendah dari jiwa spiritual manusia. Pada tingkatan ini nafsu mendominasi kepada ajakan untuk berbuat kejahatan. Hal ini menyebabkan orang dengan Nafs Amarah tidak dapat mengontrol kepentingan dirinya, tidak memiliki moral dan rasa kasih sayang. Pribadi mereka dihiasi dengan dendam, kemarahan, ketamakan, gairah seksual, iri hati, egois, dll. Kehidupan mereka rusak karena kecanduan kepada perilakuperilaku negatif, mereka menolak adanya masalah. Sehingga mudah melarikan diri dan melampiaskan masalah tanpa kendali akal sehat. Orang yang mengidap Nafs Amarah, kesadaran dan akal dikalahkan oleh keinginan dan nafsu hewani, meraka tidak dapat berubah karena tidak memiliki kebutuhan utuk berubah.

Nafs lawwamah (The regretful self), adalah manusia yang memiliki kesadaran terhadap perilakunya, dapat membedakan yang baik dan yang buruk, menyesali kesalahan-kesalahannya, namun belum memiliki kemampuan untuk mengubah gaya hidupnya dengan cara yang signifikan. Ibarat seorang pecandu yang mulai memahami rasa sakit, namun kecanduan yang kuat menyebabkan mereka tidak dapat segera berubah. Pada tahap ini dibutuhkan obat yang lebih kuat, dosis awal terap yang diberikan adalah mengikuti kewajiban yang diberikan agamanya seperti shalat, puasa, membayar zakat dan mencoba berperilaku baik. Seseorang yang mengidap nafs Lawwamah, diintai oleh tiga bahaya besar yaitu kemunafikan, kesombongan dan kemarahan. Kemunafikan timbul ketiaka mereka menginginkan orang lain mengetahui bahwa dirinya sedang be rusaha berubah dengan menunjukkan segala kebaikan di depan orang lain dan mengharapkan pujian. Kesombongan terjadi karena memandang bahwa apa yang sedang dilakukannya merupakan prestasi terbaik, dan kemarahan timbul ketika merasa tidak merasa dirinya tidak dihargai. Pada tingkatan ini, manusia tidak mampu membebaskan diri dari godaan, kekecewaan terhadap penghragaan dari orang lain terhadap eprilakunya membuatnya kembali kepada perilaku buruk. Ia merasa mengambil jalan yang salah karena kurang dihargai bahkan menyalahkan orang lain yang membawanya pada tahap ini. Ia kembali terpengaruh dengan nafsu hewani yang mereka miliki, namun cukup cerdas untuk menghadapi kekecewaan, kemunafikan, kesombongan dan kemarahan. Semakin lama orang berada pada tahap ini semakin banyak godaan yang diterima

Nafs mulhimma (The inspired self), merupakan tahap ketika seseorang sudah mulai merasakan ketulusan dari ibadahnya. Mereka termotivasi kepada cinta kasih, pengabdian dan nilai-nilai moral. Meskipun belum terbebas dari keinginan dan ego, motivasi dan pengalaman spiritual dapat mengurangi keinginnanya untuk berbuat salah. Seseorang yang berada pada tingkatan nafs Mulhima sangat penting untuk hidup dalam nilai-nilai yang lebih tinggi, agar kebaikan-kebaikan yang dirintisnya tidak memudar dan mati. Perilaku umum orang dengan nafs Mulhimma adalah kelembutan, kasih sayang, kreativitas dan tindakan moral yang baik, secara umum memiliki emosi yang matang, menghargai dan dihargai orang lain. Seseorang dengan Nafs mulhimma mendapatkan pesan dari nuraninya yang memberikan inspirasi ke arah dan tujuan yang baik, bahakan mendorongnya untuk memperkuat usahanya. Namun kadangkala kejahatan menyamar dalam bisikan nurani dan mendorongnya untuk melakukan sesuatu yang tampaknya baik padahal tidak. Oleh karena itu penting bagi mereka untuk terus belajar membedakan kedua dorongan ini, mereka seperti di dalam badai. Cara untuk menyelamatkan mereka adalah dengan mematuhi ajaran agama dan berhati-hati atas segala perbuatannya, karena mereka harus selalu berperang dengan ego. Kekalahan menyebabkan mereka hilang ketakwaannya kepada Allah 
Swt dan berani melakukan berbagai macam dosa atas nama Allah dan menjadi budak kejahatan.

Nafs muthmainnah (The Contented Self), adalah jiwa spiritual bagi orang sudah mampu merasakan kedamaian, karena kepentingan diri mulai lenyap dan lebih dekat kepada Tuhannya. Pada tahap ini seseorang berada pada periode transisi, mampu berpikiran terbuka, bersyukur, dapat dipercaya, penuh kasih sayang, sehingga dapat melepaskan semua belenggu diri mulai melakukan integrasi kembali semua aspek universal kehidupan dalam dirinya. Tahap ini dicapai setelah melalui perjalanan panjang melawan segala bentuk hawa nafsu dan kejahatan di dalam dirinya. Mereka telah meninggalkan nafsu hewani dan menghiasai diri dengan nafsu insani yang menerima perintah dan aturan agama sebagaimana dicontohkan oleh Nabi Muhammad Saw. Kualitas perilaku mereka tinggi, mereka adalah orang pemurah, penyabar, ikhlas, bersyukur, bahagia, pemaaf dan damai. Orang yang memiliki nafsu muthmainnah menjadi guru bukan hanya dengan katakatanya tetapi dengan perbuatannya, perilaku mereka selalu berhubungan dengan peraturan agama, mereka akan mendapat bimbingan dari Allah, karena sikap berserah diri dan bergantung hanya kepada Allah.

Nafs radhiyah (The pleased self) adalah orang yang telah mencapai jiwa spiritual tenang dan bahagia baik dalam keadaan lapang maupun sempit dengan segala cobaan musibah hidupnya. Ia menyadari segala cobaan berasal dari Allah Swt untuk memperkuat keimanannya. Kebahagiaannya tidak bersifat hedonistik atau materialistik, namun bahagia itu timbul karena mencintai dan bersyukur kepada Allah. Mereka berada pada tahta spiritual, sehingga tidak ada kemungkinan salah karena mereka telah mampu menguasai nafsu-nafsu buruk mereka, dunia luar melayani mereka, ketakwaan, kepasrahan, kesabaran, kesyukuran dan kecintaan kepada Allah demikian sempurna, sehingga Allah menggapi dengan cepat doa-doa mereka karena mereka adalah hamba yang kembali kepadaNya.

Nafs mardhiah (The self Pleasing to God) adalah orang-orang yang menyadari bahwa segala kekuatan berasal dari Allah, an tidak dapat terjadi begitu saja. Mereka tidak lagi mengalami rasa takut dan tidak meminta, mereka telah mencapai keatuan internal. Ibarat kaca yang pecah, mereka mampu menyatukan perpecahan tersebut menjadi utuh. Mereka adalah insan kamil yang memiliki ikatan antara Khaliq dengan makhluk, Nama dan sifat Allah termanifestasi dalam diri mereka. Mereka melihat keindahan dalam segala hal, memaafkan segala kesalahan yang tidak diketahui, mereka sabar, murah hati, selalu memberi tidak pernah meminta, mengabdi dengan membawa orang lain kepada cahaya jiwa, melindungi orang lain dari bahaya nafsu dan kegelapan dunia, segalanya dilakukan demi Allah dalam nama Allah.

Nafs safiyah (The pure self) adalah tahap akhir mengalami transendensi diri yang seutuhnya. Tidak ada nafs yang tersisa, mereka menyadari kebenaran sejati dari pernyataan "tidak ada Tuhan selain Allah". Inilah spiritual tertinggi yang disebut manusia suci, tidak ada keluhan dan keinginan, mereka memiliki jiwa yang murni, gerakannya adalah kasih sayang, kata-katanya adalah kebijaksanaan ibarat musik yang indah didengar oleh teliga, seluruh keridhaannya adalah ibadah, setiap ruas tubuh dan sel memuji Allah. Mereka sederhana, meskipun tidak pernah berbuat dosa, mereka selalu mengeluarkan air mata taubat. Kebahagiaan mereka adalah melihat manusia lain dapat mencapai Tuhannya dan rasa sakit mereka adalah jika mereka melihat orang-orang menjauhi Tuhannya. Mereka mencintai orang yang mengabdi kepada Allah lebih dari segalanya. Mereka marah jika melihat orang yang durhaka. Apa yang diinginkannya dari manusia adalah apa yang Allah inginkan dan takut pada nasib orang-orang yang tidak beriman. Mereka 
termasuk orang berusaha menyadarkan orang-orang yang berdosa.

Komitmen dan keyakinan dalam menjalankan syariat agama yang tidak terlepas dari kekuatan spiritual dapat dianggap sebagai kendali bagi manusia dalam memilih jalan hidup yang baik, sehingga tujuan pendidikan spiritual terhadap nilai moral adalah sebagai penuntun bagi seorang manusia dalam melaksanakan perilaku dan sifat baik sesuai dengan tuntunan syariat agama dalam kehidupan pribadi, bermasyarakat, berbangsa dan bernegara

\section{Nilai Moral}

Nilai telah diartikan oleh para ahli dengan berbagai pengertian, dimana pengertian satu berbeda dengan yang lainnya. Adanya perbedaan pengertian tentang nilai ini dapat dimaklumi oleh para ahli itu sendiri karena nilai tersebut sangat erat hubungannya dengan pengertian-pengertian dan aktivitas manusia yang kompleks dan sulit ditentukan batasannya. Nilai pada dasarnya merupakan sifat-sifat atau halhal yang penting atau berguna bagi kemanusian, "nilai adalah sesuatu yang bersifat abstrak, ia ideal, bukan benda kongkrit, bukan fakta, bukan hanya persoalan benar dan salah yang menuntut pembuktian empirik, melainkan soal penghayatan yang dikehendaki dan tidak di kehendaki, disenangi dan tidak disenangi" (Purwadarmita., 1999:667). Secara filosofis, nilai sangat terkait dengan masalah etika dan biasa juga disebut filsafat nilai yang mengkaji nilai-nilai moral sebagai tolak ukur tindakan dan perilaku manusia dalam berbagai aspek kehidupannya. (Al Munawar, 2003: 4)

Hal ini berarti untuk melacak sebuah nilai harus melalui pemaknaan terhadap kenyataan lain berupa tindakan, tingkah laku, pola pikir dan sikap seseorang atau sekelompok orang. Nilai dan moral merupakan dua konsep berbeda yang dalam penggunaannya seringkali disandingkan. Nilai berperan dalam suasana apresiasi atau penilaian dan akibatnya sering akan dinilai secara berbeda oleh orang banyak. Nilai selalu berkaitan dengan penilaian seseorang atau sebagai rujukan dan keyakinan baik berupa norma, etika, peraturan, undangundang, adat kebiasaan, aturan agama dan rujukan lainnya yang memiliki harga dan dirasakan berharga bagi seseorang dalam menjalani kehidupannya.

Nilai bersifat abstrak yang berada di balik fakta (hal objektif), sehingga dapat mewujudkan tindakan karena nilai terdapat dalam moral seseorang yang muncul sebagai akhir proses psikologis. Moral itu sendiri muncul dari potensi emosi yang mendorong seseorang untuk berbuat baik atau buruk, karena moralitas merupakan lambang humanitas yang tertinggi karena memang ia diciptakan untuk tujuan tersebut. Moral merupakan kondisi pikiran, perasaan, ucapan, dan perilaku manusia yang terkait dengan nilai-nilai baik dan buruk. Moral secara ekplisit berhubungan dengan proses sosialisasi individu, tanpa moral manusia tidak bisa melakukan proses sosialisasi. Moral adalah nilai keabsolutan dalam kehidupan bermasyarakat secara utuh. Penilaian terhadap moral diukur dari kebudayaan masyarakat setempat.

Moral adalah perbuatan/tingkah laku/ucapan seseorang dalam berinteraksi dengan manusia. Apabila yang dilakukan seseorang itu sesuai dengan nilai rasa yang berlaku di masyarakat tersebut dan dapat diterima serta menyenangkan lingkungan masyarakatnya, maka orang itu dinilai memiliki moral yang baik, begitu juga sebaliknya. Moral merupakan produk dari budaya dan agama. Moral juga dapat diartikan sebagai sikap, perilaku, tindakan, kelakuan yang dilakukan seseorang pada saat mencoba melakukan sesuatu berdasarkan pengalaman, tafsiran, suara hati, serta nasihat, dll.

Maka dapat disimpulkan bahwa nilai moral adalah sifat-sifat atau hal-hal yang penting atau berguna bagi kemanusian yang dilakukan secara terencana untuk mengubah sikap, perilaku, tindakan, kelakuan agar mampu berinteraksi dengan 
lingkungan masyarakatnya sesuai dengan nilai agama dan moral serta kebudayaan masyarakat setempat. Bernard Shaw mengatakan "manusia yang berhasil meraih sukses besar di dunia adalah mereka yang bangun dan mencari keadaan yang mereka inginkan. Kalau mereka tidak berhasil menemukannya, mereka akan menciptakan keadaan tersebut" (Muhyidin, 2003:86)

Dalam hal ini, potensi psikis berupa akal, kemauan, dan perasaan mesti senantiasa diarahkan pada nilai-nilai moralitas yang tertinggi, dimana kondisi fitrah manusia memerlukan pemeliharaan dan pengembangan melalui penyiapan berbagai perangkat pendukung bagi lahirnya perilaku moral potensial menjadi perilaku moral aktual. Fitrah merupakan jiwa kemanusiaan yang perlu dilengkapi dengan tabiat beragama. Fitrah kemanusiaan dan tabiat beragama merupakan relasi yang utuh karena keduanya merupakan ciptaan Allah pada diri manusia sebagai potensi dasar yang memberikan hikmah, mengubah diri ke arah yang lebih baik, mengobati jiwa yang sakit dan meluruskan diri dari berpaling. Manusia ideal dalam Islam yaitu manusia yang memiliki kepribadian moralis, baik fungsinya sebagai mu'abbid, khalifah fi alardh, dan 'immarah fi al-ardh (Q.S AliImran:110).

\section{Penyebab Krisis Nilai Moral}

Faktor-faktor yang menyebabkan timbulnya perilaku menyimpang yang pada akhirnya menimbulkan krisis moral, diantaranya adalah:

\section{1) Longgarnya pegangan terhadap agama.}

Sudah menjadi tragedi dari dunia maju, dimana segala sesuatu hampir dicapai dengan ilmu pengetahuan, sehingga keyakinan beragama mulai terdesak, kepercayaaan kepada Tuhan tinggal simbol, larangan dan suruhan Tuhan tidal lagi di indahkan lagi. Dengan longgarnya pegangan seseorang pada ajaran agama, maka hilanglah kekuatan pengontrol yang ada di dalam dirinya. Dengan demikian satu-satunya pengontrol adalah masyarakat dengan hukum dan peraturannya. Akan tetapi jika setiap orang teguh keyakinannya kepada Tuhan serta menjalankan agama dengan sungguh-sungguh, tidak perlu lagi adanya pengawasan yang ketat, karena setiap orang sudah dapat menjaga dirinya sendiri.

\section{2) Kurangnya internalisasi nilai moral melalui pendidikan karakter}

Kurangnya internalisas nilai moral adalah salah satu penyebab turunnya moral bangsa kita baik itu dalam bangku sekolah, dan kurangnya perhatian dari guru sebagai pendidik dalam hal pembentukan karakter peserta didik, sehingga peserta didik lebih banyak terfokus pada aspek kognitif dan kurang memperhatikan aspek afektif dalam pembelajaran. Hasilnya adalah peserta didik pintar dalam hal pelajaran tertentu, namun mempunyai akhlak/moral yang kurang bagus. Banyak di antara peserta didik yang pintar jika mengerjakan soal pelajaran, namun tidak hormat terhadap gurunya, suka mengganggu orang lain, tidak mempunyai sifat jujur, malas, dan sifat-sifat buruk lainnya. Tingginya angka kenakalan dan kurangnya sikap sopan santun peserta didik, dipandang sebagai akibat dari kurang efektifnya sistem pendidikan saat ini. Ditambah lagi dengan masih minimnya perhatian guru terhadap pendidikan dan perkembangan karakter peserta didik. Sehinga sebagian peserta didik tidak mempunyai karakter positif. Pendidikan tanpa karakter hanya akan membuat individu tumbuh secara parsial, menjadi sosok yang cerdas dan pandai, namun kurang memiliki pertumbuhan secara lebih penuh sebagai manusia. Hal tersebut sudah dicontohkan dalam sistem pendidikan kita pasca reformasi. Kurikulum yang dibangun untuk mencerdaskan kehidupan justru berujung kepada penurunan moral dari sebagian perserta didiknya. 
3) Kurang efektifnya pembinaan moral yang dilakukan oleh rumah tangga, sekolah maupun masyarakat.

Pembinaan moral yang dilakukan oleh ketiga instintusi ini tidak berjalan menurut mana yang semestinya. Pembinaan moral di rumah tangga misalnya dan dilakukan dari sejak masih kecil, sesuai dengan kemampuan dan umurnya, karena setiap anak lahir, belum mengerti mana yang salah dan mana yang buruk. Pembinaan moral pada anak di rumah tangga bukan dengan cara menyuruh anak menghafalkan rumusan tentang baik dan buruk, melainkan harus di biasakan. Tidak efektifnya pembinaan moral akan menyebabkan lemahnya mental generasi bangsa yang terbentuk sejak dini, sehingga membentuk karakter yang kurang baik. Karakter tersebut akan menjadi watak perilku seseorang dalam menjalani kehidupan. Untuk mengatasi masalah tersebut, maka perlu diupayakan pembentukan karakter sejak dini

4) Derasnya arus budaya materialistis, hedonistis dan sekularististis dan Penyalalah gunaan sebagian ajaran moral

Pada saat ini gejala penyimpangan moral terjadi karena pola hidup yang semata-mata mengejar kepuasan materi, kesenangan hawa nafsu dan tidak mengindahkan nilai-nilai agama. Hal ini dibuktikan dengan maraknya kasus penipuan, perdagangan narkoba, penggunaan alat-alat kontrasepsi ilegal, prostitusi dsb yang seluruh hal tersebut biasanya menjerumuskan dan dapat merusak moral. Timbulnya sikap tersebut tidak bisa dilepaskan dari derasnya arus budaya matrealistis, hedonistis dan sekularistis yang mendorong manusia menyalahgunakanajaran moral dalam berbagai bentuk dan cara. Mereka yang telah dirasuki ketamakan, terutama apabila mempunyai kekuatan dan pengaruh, tidak akan ragu-ragu dalam memakai segala cara untuk mencapai tujuannya.

5) Perkembangan Teknologi
Krisis nilai moral juga diakibatkan oleh perkembangan teknologi saat ini. Dengan kemudahan akses internet, tidak ada lagi batas lagi yang mampu menghalangi seseorang untuk melanggar nilai moral mulai dari hal-hal kecil sampai dengan hal-hal besar seperti prostitusi online.

\section{Solusi Dari Permasalahan Krisis Nilai Moral}

Ada beberapa hal yang harus diperbaiki untuk menanggulangi masalah krisis moral ini, diantaranya:

\section{1) Menghargai sesama Manusia}

Bagi seorang muslim, Rasulullah Shallalahualaihi wasallam merupakan sumber keteladanan yang telah bersabda bahwa Beliau diutus untuk menyempurnakan martabat dan derajat manusia. Rasulullah menjadi muaddib dari sikap moral yang terbaik seperti alim, toleran, menghargai dan menghormati, sabar, murah hati, berani, mempunyai harga diri, bermoral, berterus terang, jujur, memiliki harga diri, dll. Memiliki harga diri (self-respect) artinya segala sesuatu harus diperhitungkan kebaikan dan keburukannya, manfaaat dan mudharatnya dan mempertimbangkan segala tindakan yang akan bisa mengembangkan kematangan spiritualnya, dan mengangkat posisinya agar bermanfaat bagi seluruh makhluk lain di muka bumi. Beberapa sifat tertentu seperti toleran dan pengorbanan diri adalah masalah penghargaan diri dan tanda keterbukaan hati dan kebesaran jiwa. Kualitas seperti ini hanya akan dimiliki oleh orang yang yang selalu bisa mengendalikan diri dan tidak egois (selfcentered), dan dengan realistis mengakui hal-hal baik dalam diri orang lain dan menghormatinya. Sifat-sifat mulia tersebut yang membentuk landasan karakter yang mulia, adalah bagian dari nilai-nilai moral yang tinggi.

\section{2) Mendekatkan diri dengan Allah}

Hanya sifat-sifat mulia yang telah disebutkan diatas yang akan mendekatkan manusia dengan Tuhannya. Pengamalan 
Islam yang kaffah ditandai dengan peningkatan kualitas keimanan yang menjunjung tinggi ajaran syariat, adanya perbaikan akhlak yang menyeluruh, penguatan fisik dan penyehatan jiwa. Keyakinan transendental ini mengandung nilai spiritual untuk membentengi seseorang dari berbagai jalan kemaksiatan dan kesesatan. Spiritualitas adalah keinginan dan kegiatan dalam bentuk immateri untuk menemukan Tuhan yang Maha Esa. Melalui transformasi jiwa spiritual, seorang muslim mampu mengubah pembangkangan menjadi kepatuhan kepada Allah. Spiritual hadir dalam diri sebagai suatu kebangkitan atau pencerahan diri dalam mencapai tujuan dan makna hidup, yang berarti juga bagian esensial dari keseluruhan definisi sehat dan sejahtera bagi seorang muslim. Proses spiritual dimulai dengan tumbuhnya kekuatan internal yang mengubah hubungan seseorang dengan tuhan dan dilanjutkan dengan peningkatan realitas fisik seseorang akibat perubahan internal. "Perubahan akan timbul pada diri seseorang dengan meningkatnya kesadaran, dimana nilai-nlai ketuhanan di dalam dirinya akan termanifestasi ke luar melalui pengalaman dan kemajuan dir"i (Aliah, 2006: 289)

\section{3) Menguatkan fungsi pendidikan}

Sesuai dengan Undang-Undang No. 20 Tahun 2003 tentang sistem Pendidikan Nasional Pada Pasal 3, yang menyebutkan bahwa pendidikan Nasional berfungsi mengembangkan kemampuan dan membentuk karakter serta peradaban bangsa yang bermartabat dalam rangka mencerdaskan kehidupan bangsa, Pendidikan Nasional bertujuan untuk mengembangkan potensi peserta didik agar menjadi manusia yang beriman dan bertakwa kepada Tuhan Yang Maha Esa, berakhlak Mulia, berilmu, sehat, cakap, kreatif, mandiri, dan menjadi warga Negara yang demokratis serta bertanggung jawab. Namun, jika kita melihat kondisi pendidikan di Indonesia sekarang ini, ternyata masih belum sesuai dengan yang diharapkan. Proses pendidikan belum sepenuhnya berhasil membangun manusia Indonesia yang berkarakter positif. Bahkan, banyak yang menyebut, pendidikan telah gagal membangun karakter. Banyak lulusan sekolah dan sarjana pintar dalam bangku sekolah atau perkuliahan dan piawai dalam menjawab soal ujian, berotak cerdas, tetapi lemah dalam hal mental, penakut, dan perilakunya tidak terpuji. Di sisi lain, pendidikan yang bertujuan mencetak manusia yang cerdas dan kreatif serta beriman dan bertaqwa kepada Tuhan Yang Maha Esa, belum sepenuhnya terwujud. Hal ini terlihat dari banyaknya kasus pelajar yang terlibat tawuran, kasus kriminal, narkoba, seks di luar nikah, dan kasus-kasus yang lain.Berbagai upaya telah dilakukan oleh pemerintah, dalam hal ini Menteri Pendidikan, untuk memperbaiki moral generasi bangsa melalui pendidikan. Namun keinginan tersebut ternyata belum membuahkan hasil yang signifikan. Pemerintah dalam melaksanakan pendidikan, masih lebih banyak menitikberatkan pada kemampuan kognitif siswa, dengan mengesampingkan kemampuan afektif atau perilaku siswa dan psikomotorik atau keterampilanSalah satu solusi agar pendidikan moral menjadi efektif adalah dengan menerapkan pendidikan karakter di setiap jenjang pendidikan, mulai dari pendidikan dasar sampai pada pendidikan tinggi. Pendidikan karakter adalah suatu sistem penanaman nilai-nilai karakter kepada warga sekolah yang meliputi konsumen pengetahuan, kesadaran dan kemauan dan tindakan untuk melaksanakan nilai-nilai tersebut baik terhadap Tuhan Yang Maha Esa, diri sendiri, sesama, lingkungan maupun ke bangsa sehingga menjadi insan kamil. Dengan penerapan pendidikan karakter, maka karakter dari peserta didik akan terbentuk sejak mereka berada di bangku sekolah dasar, kemudian dilanjutkan pada sekolah menengah dan perguruan tinggi. Dengan terbentuknya karakter tersebut, maka akan menjadi perisai atau kontrol dalam diri seseorang, sehingga akan mengendalikan perilaku 
orang tersebut. Intinya adalah, jika karakter sudah terbentuk, maka akan sulit untuk mengubah karakter tersebut. Dengan menanamkan nilai-nilai kebaikan dalam setiap proses pendidikan, akan membantu proses pembentukan karakter dari peserta didik yang bermoral dan bermartabat.

Dengan terbentuknya karakter tersebut, maka karakter tersebut akan sulit hilang sehingga akan menjadi watak perilaku seseorang dalam menjalani masa yang akan datang. Penerapan pendidikan karakter dalam sistem kurikulum pendidikan dapat dilaksanakan dengan cara : 1) Menyisipkan nilai-nilai moral di setiap proses belajar mengajar, 2) Membentuk kelas motivasi (motivation class), yang dalam hal ini lebih menekankan pada penggugahan motivasi internal peserta didik, 3) Menambah mata pelajaran tentang pendidikan moral, dan peserta didik dipersyaratkan lulus mata pelajaran tersebut, 4) Mata pelajaran yang substansinya sudah mengandung nilainilai moral hendaknya lebih aplikatif, tidak hanya text book semata, 5) Menyeimbangkan porsi antara materi belajar akal (cerdas) dan hati (moral). Dalam hal ini guru, Departemen Pendidikan Nasional, dan masyarakat pemerhati pendidikan untuk bersamasama mengupayakan penerapan pendidikan karakter ke dalam sistem kurikulum pendidikan.

\section{SIMPULAN}

Seseorang yang mengalami krisi nilai moral berarti sedang berada pada level terendah dari tingkatan spiritual. Dalam pandangan Islam, terdapat tujuh tingkatan spiritualitas manusia dari yang bersifat egoistik sampai yang suci menurut perintah Allah. Tingkatan itu terdiri dari nafs amarah, nafs lawwamah, nafs mulhimma, nafs muthmainnah, nafs radhiyah, nafs mardhiah dan nafs safiyah. Krisis nilai moral adalah permasalahan yang sangat kompleks, yang dapat merusak tatanan hidup bermasyarakat.
Maka solusinya adalah seseorang harus mampu hidup damai dengan sesama dengan cara menghargai sesama, selau mendekatkan diri kepada Allah. Disamping itu juga sangat diperlukan peran dari pemerintah, orang tua dan masyarakat dalam menguatkan fungsi pendidikan.

\section{DAFTAR PUSTAKA}

Aliah B. \& Purwakania H., (2006), Psikologi Perkembangan Islami, Menyingkap Rentang Kehidupan Manusia Dari Prakelahiran Hingga Prakematian, Jakarta: Raja Grafindo Pers

Ginanjar, A., (2013), ESQ, Emotional;, Spiritual Quotient Berdasakan Rukun Iman dan Rukun Islam, Jakarta.

Mohar, D., \& Ian M., (2007), Spiritual Questions, terjemahan Rahmani Astuti, dkk, Bandung: Mizan

Jamaluddin, I., (2010), Quantum Thinking For Muslim. Terjemahan Dennis Arisandi Pakih Suci, cet I, Yogyakarta: Mirza Media Pustaka

http://patriarizko12.blogspot.com/2009/10/pen gertian-obyektivasi-internalisasi.html

Najati, M.U., (200o), Al Haaditsun Nabawiy Wa 'Ilmun Nafs, terjemahan Wawan Djunaeidi, Jakarta: Mustaqiem.

Musthafa, S.F., (2009), Minhajuth Thiflil Muslim, terjemahan Wafi Marzuqi Ammar, Surabaya: Pustaka Elba

Rivai, S. \& Sylviana M, (2009), Education Management, Analisis Teori dan Praktek, Jakarta: Raja Grafindo 